\title{
Multimodal Analysis of Car Advertisements
}

\author{
Eka Kuswandini, Universitas Airlangga
}

\begin{abstract}
:
Critical discourse analysis (CDA) has an interest in concepts like communication patterns in public institutions, media discourse (reports, advertisements discourse, television broadcasts etc.), the constitution of individual and group identity that convey ideological attitudes, power and status. One of the media discourse used in this study is advertisement discourse. The researcher took three popular and most brand values; they are Toyota, Mercedes-Benz and BMW produced in 2017. The aim of this study is to analyze the data using CDA and semiotic analysis. The researcher used qualitative method in the methodology approach. The result showed that all the advertisements have many aspects based on the good advertisement.
\end{abstract}

Keywords: advertisement discourse; car advertisement; critical discourse analysis; multimodal discourse analysis; semiotic analysis

\section{Introduction}

Language is one of communication tools which is used directly. It can be in written or spoken form. It is also related to communication devices such as television, radio, newspaper, magazines, internet or other medias. Language is used to give information and persuade the other people. Because of that reason, language is implemented in advertisement.

Language used in advertisement must be easy to understand, catchy and persuasive, because advertisement itself has to persuade the customer to buy and use the product (Sunardi, 2014).

Cook (2001) points out that the function of advertisements is to inform, persuade, remind, influence and perhaps change opinions, emotions and attitudes. In short, advertisements do not only sell products but change society and make people buy things they do not want or need through visuals and language used to attract attention.

Car as a transportation in this country has many interested people and users. Now days many people can buy car with low cost and high cost based on their budget. Car is a useful product for many people. It can be for business, private activities or for rent. So, many car exhibitions are held in many cities in Indonesia. Every showroom of car races to attract the buyer to buy the product by many ways such as giving the buyer a piece of paper which contains the type of the cars and also the tagline in every different car. Advertisement is a powerful tool of communication to persuade people to buy the product advertised (Dyer, 1996). Hereby, the advertisement plays an important role in conveying message of the product. Advertisement, in a simple word, means drawing attention to something or notifying/informing something to somebody (Dyer, 1996). In this study the researcher takes three data; they are Toyota, Mercedes- Benz and BMW as popular and brand value in 2017 based on Kompas.com.

\section{Literature review}

One of the theories available for analyzing media discourse is the one introduced by Kress and Van Leeuwen (2006) namely grammar of visual design. It presents a framework for analyzing and understanding visual images, and the interaction between verbal and visual components in media discourses. Gunther Kress and Theo Van Leeuwen, two forerunners of a comprehensive theory of visual communication, have considered semiotic modes other than language in various kinds of discourses. They point out the changing patterns in mass communication where the boundaries between language and visual elements in printed material are becoming less in number.

Kress and Van Leeuwen indicate that all texts are multimodal (1998), to mean paralinguistic means of communication such as rhythm, intonation, facial expressions, gesture etc. accompanying spoken language, and written language are always a visual composition of 
marks on a page. They argue that most work done in CDA has focused on verbal texts, or on the verbal parts of multimodal texts. With their theory of grammar of visual design, they intend to broaden the approach suggested by CDA, to include the structure and use of images. The important role of images in newspapers, magazines, public relations materials, advertisements and various kinds of books is noted (Kress \& Van Leeuwen: 1996). Kress and Van Leeuwen (1996) also stress that "the visual component of a text is an independently organized and structured message, connected to the written component, but not necessarily dependent on it, that is, they are neither fully conflated, nor entirely opposed.

Multimodality views communication and representation as more than language; it places more attention on other modes of communication such as the visual mode of images, gesture, gaze, posture, colour, typography, composition etc. (Van Leeuwen, 2005; Kress and Van Leeuwen, 2006; Machin, 2007; Jewitt, 2009) claiming that these elements transfer and generate meaning, especially in relation to each other. Kress and Van Leeuwen (2006) state the meaning potential of individual elements is the element's ability to convey meaning. However, it is possible to realize an element's full meaning only if it exists as a collective whole (Machin, 2007; Kress \& Van Leeuwen, 2006). The mission of Multimodal Discourse Analysis (MDA) is to understand the power and meaning of texts activating several modes (such as visual, verbal, and aural) (Kress and van Leeuwen, 2006; Machin, 2007; Jewitt, 2009). The systematic deconstruction of texts through semiotic analysis is possible with this new trend in discourse analysis. MDA has been used in the analysis of a wide range of domains, e.g. the analysis of magazine covers (Machin \& Thornborrow, 2003), magazine advertisements (Bell \& Milic, 2002), movies (Maiorani, 2007), children's storybooks (Guijarro \& Pinar Sanz, 2008), online advertisements (Harrison, 2008), beauty product ads (Harrison, 2008), moving images (Maiorani, 2007), commercials (Nina-Pazarzi \& Tsangaris, 2008), cosmetic surgery leaflets (Martinez Lirola \& Chovanec, 2012), and surgical websites (Moran \& Lee, 2013). To Jewitt (2009) there are three different approaches to conduct multimodal analysis. The first approach is referred to as the social semiotic multimodality (Jewitt, 2009). This approach focuses on meaning making through choices (Jewitt, 2009). The second approach is MDA, which was also developed by Kress and Van Leeuwen (2001) and follows Halliday's work. The distinction between these two approaches is their emphasis on the sign-maker. While the social semiotic multimodality approach places higher emphasis on the sign-maker, the MDA approach places low emphasis on the sign-maker (Jewitt, 2009). Finally, the third approach that Jewitt outlines is the multimodal interactional analysis. As Jewitt (2009) points out, this approach addresses a dimension of the social semiotic that conventional multimodal analysis does not seem to commonly address and focuses on how multimodal texts are interfaced with and mediated by people. The approach that will be utilized in this study is MDA, following the program of Kress and Van Leeuwen (2001; 2006) and Machin (2007).

\section{Methodology}

This study uses descriptive content analysis. It is called descriptive because it is designed to obtain information, to determine the nature of situation as it exists and finally describe what exists in current study. Qualitative research means for exploring and understanding the meaning individuals or groups ascribe to a social or human problem. The process of research involves emerging questions and procedures. Data typically collected in the participant's setting. Data analysis inductively builds from particulars to general themes. And the researcher makes interpretations the meaning of the data. The final written report has a flexible structure. Those who engage in this form of inquiry support a way of looking at research that honors an inductive style, a focus on individual meaning, and the importance of rendering the complexity of a situation (Creswell. 2007).

The researcher takes the data by download from internet source and chooses the best advertisement from three brands of car, they are Toyota, Mercedes-Benz and BMW. Then, the data analyzes by the researcher using the theory above. 


\section{Findings and discussion}

Figure 1: C-HR Toyota

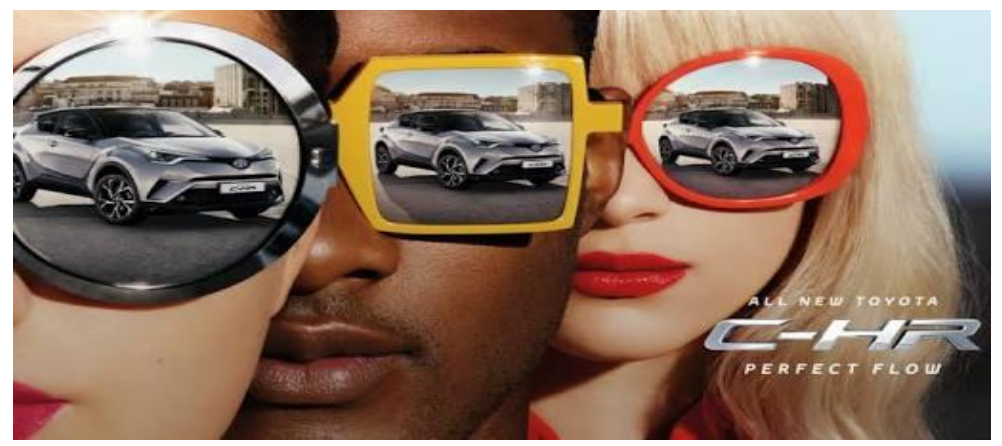

The first Value Brand is from Toyota, Toyota is one of the biggest and famous cars in the world. This car is produced in Japan, as we know Japan has advance technology in many fields one of which is in car technology not only because of the good quality and advance machine they produced but also the good marketing and the used of advertisement as a media to promote the product. Figure 1 above is an advertisement of C-HR Toyota. The unique concept they used is catchy in the eyes. In the advertisement, there is usually only a big picture of a car they sell but in the picture above there are three models; they are two women and a man, with different skin, hair color. The biggest point is the glasses that the models are wearing have different models, colors and sizes. The view seen on their glasses shows their perspective which means the car is suitable for them and whoever you are you can use that car. In additions, the tagline in this advertisement is perfect flow. Perfect is the best word to describe the best thing we see, and flow means how we drive the car with perfect ways. The use of bright color make the advertisement looks alive. Black, yellow, red, white, grey and others colors show us the contrast and the tight impression.

The modes and the sign used in the advertisement are good and can make the perspectives of the customer change. Two women is the point showing that the car is perfect for women too not only for men. Thus as a whole the concept of the advertisement is appropriate.

Figure 2: Mercedes-Benz

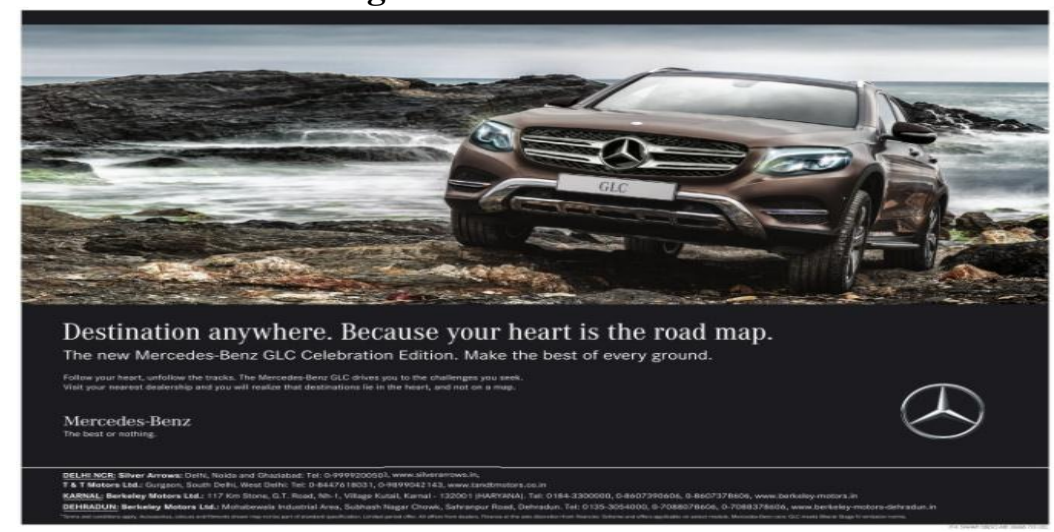

Mercedes-Benz is an automotive company from German which makes and produces many kinds of vehicles. Mercedes-Benz is one of luxurious car in the world. Using its image and its design the company persuade many customers from many countries to buy it. One of the strategies in marketing the product is by advertising it to show all the people about the product the company sells. 
From the advertisement above we can see a big picture of a car with the background of the edge of the beach which has rocky ground. It means that the customer can use the car to go everywhere including in the hard ground such as at the side of beach, mountain, or on the hill. It can change the perspective of the customer who always think that Mercedes-Benz cars are only used in the city area. Mercedes-Benz also promotes that the car they produce also can take the customer to everywhere. The view of the front side of the car can create the stronger point which means the fronts side is the best part and most customers tend to see the front side of the car than the other side. The tagline appeared on the ads is Destination anywhere. Because your heart is the road map, which means you or the customer can drive to everywhere and do not worry about the car because the car has advance technology, and wherever the customers want to go the customer can use the road map which is available inside the car and inside the heart of the customer. The first function of the ads is the customers buy and drive the car and the customers can easily go everywhere without worrying about the type of the car suitable with the area or location the customers want to go.

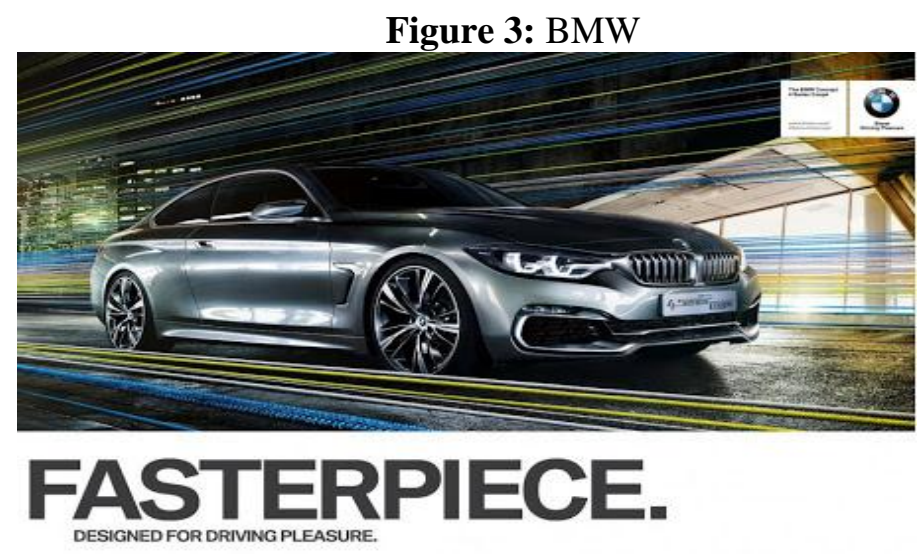

The last advertisement is BMW. BWM is an automotive company which produces car and motorcycle. BMW AG is a main company of some brand cars, they are MINI and RollsRoyce. The image of BMW is the same as Mercedes-Benz car which is luxurious and extravagant car. It has expensive price different from Toyota which has many various price even the customer with low salary can buy the car.

In the advertisement, the big picture of the car is shown up. With the background of the city looks in which there are some bright buildings beside the car, it means that the car is suitable in the city area and the blue and yellow light show us that the car is very fast. It means the technology is advance in their type. The picture of the car has two sides, front side and beside side to make the customer more interested and give the perfect looks of the car. The tagline of the advertisement is Fasterpiece. Designed for driving. The word 'Fasterpiece' is from masterpiece and is changed into fasterpiece, masterpiece itself has the meaning of the great work. It becomes fasterpiece means faster work, so the point is the car has fast technology presented to the customer with luxurious looks and high technology may make the customer interested to buy it. Furthermore, under the word fasterpiece there is a sentence designed for driving pleasure means attracting the attention to the customer and assuring that the car is very comfortable and enjoyable for driving.

\section{Conclusion}

One of the functions of the advertisement is for promoting and marketing the product. With the unique and best concept of the product advertisement can deliver the meaning and describe the product to the customers perfectly. Advertisement also one of the media for the customers to find the description of the product which they want to buy, so the advertisement is also needed not only for the company but also for the customer. Advertisement can change 
people.s perspective about the product. From the best three advertisement of the car products we can conclude that they make the advertisement as unique and best concept as possible to describe the type of the car they sell and also attract them to buy it.

\section{References}

Bell, P. \& Milic, M. 2002. Goffman's Gender Advertisements Revisited: combining content analysis with semiotic analysis, Visual Communication, 1(2), 203-222.

Cook, G. 2001. Discourse of Advertising. New York, NY: Routledge.

Creswell, John W. 2009. Research Design: Qualitative, Quantitative, and Mixed MethodApproaches $\left(3^{\text {rd }}\right.$ ed). Thousand Oaks: Sage Publications.

Dyer, Gillian. 1996. Advertising as communication. London: Routledge, Clays Ltd, St Ives Pic.

Guijarro, M. J. \& Pinar Sanz, M. J. 2008. Compositional, interpersonal and representational meanings in a children's narrative: A multimodal discourse analysis. Journal of Pragmatics 40(9), 1601- 1619.

Halliday, M. A. K. 1978. Language as Social Semiotic: The social interpretation of language and meaning. London: Edward Arnold.

Halliday, M. A. K. 1985. Introduction to Functional Grammar (1st ed.). London: Edward Arnold.

Halliday, M. A. K. 1994. An Introduction to Functional Grammar. London: Longman.

Harrison, C. 2008. Real Men Do Wear Mascara: Advertising Discourse and Masculine Identity. Critical Discourse Studies, 5(1), 55-74.

Jewitt, C. 2009. The Routledge Handbook of Multimodal Analysis. London: Routledge.

Kress, G. \& Van Leeuwen, T. 1996. Reading Images: The Grammar of Visual Design. London: Routledge.

Kress, G. \& Van Leeuwen, T. 1998. Front pages: The (critical) Analysis of Newspaper layout. In Bell. A and Garrett P. (Eds). Approaches to Media Discourse. (pp. 186-219). Oxford: Blackwell,.

Kress, G. \& Van Leeuwen, T. 2001. Multimodal Discourse: The Modes and Media of Contemporary Communication. London: Arnold.

Kress, G. \& Van Leeuwen, T. 2006. Reading Images: The Grammar of Visual Design (2 $2^{\text {nd }}$ ed.). London: Routledge.

Machin, D. 2007. Introduction to Multimodal Analysis. London: Hodder Arnold Publication.

Machin, D. \& Thornborrow, J. 2003. Branding and discourse: The case of Cosmopolitan. Discourse and Society, 14(4), 453-470.

Peringkat Nilai Merek Otomotif Dunia. Available at http//otomotif.kompas.com/read/2017/09/26/121232915/peringkat-nilai-merekotomotif-dunia. Accessed on June 12 $2^{\text {th }} 2018$ )

Van Leeuwen, T. 2005. Introducing Social Semiotics. London and New York: Routledge. 